\title{
Isolasi dan Karakterisasi Enzim Bromelain dari Bonggol dan Daging Buah Nanas (Ananas comosus)
}

\section{Isolation and Characterization of Bromelain from The Core and Flesh of Pineapple Extracts (Ananas comosus)}

\author{
${ }^{1)}$ Nita Magfirah Ilyas, ${ }^{2)}$ Siswati Setiasih, ${ }^{3)}$ Sumi Hudiyono \\ ${ }^{1}$ Universitas Negeri Makassar, Jalan Daeng Tata Makassar, Kampus UNM Parangtambung \\ ${ }^{2,3}$ Departemen Kimia, FMIPA Universitas Indonesia, Kampus UI Depok \\ Email : nita.magfirah@unm.ac.id
}

\begin{abstract}
ABSTRAK
Penelitian ini bertujuan untuk mengisolasi dan memurnikan bromelain yang diekstrak dari bagian tanaman nanas (Ananas comosus) melalui metode fraksinasi menggunakan garam ammonium sulfat, diikuti dengan proses dialisis. Aktivitas spesifik tertinggi terdapat pada fraksi ammonium sulfat $50-80 \%$ (fraksi 3) baik untuk sampel bagian bonggol maupun bagian daging buah nanas, masing-masing adalah sebesar 0,30 $\mathrm{U} / \mathrm{mg}$ dan $0,21 \mathrm{U} / \mathrm{mg}$. Fraksi 3 dari bagian bonggol memiliki tingkat kemurnian 132,65 kali enzim kasarnya sedangkan fraksi 3 dari bagian daging buah nanas memiliki tingkat kemurnian 108,47 kali dari enzim kasarnya. Proses dialisis memberikan nilai aktivitas spesifik dan tingkat kemurnian enzim tertinggi pada fraksi 3 dari bagian bonggol nanas yaitu sebesar 0,33 U/mg dengan kenaikan tingkat kemurnian menjadi sebesar 141,58 kali enzim kasarnya. Uji kestabilan termal terhadap fraksi enzim hasil dialisis menunjukkan bromelain dari bonggol memiliki kestabilan termal yang lebih tinggi dibandingkan dengan bromelain dari daging buah nanas. $\mathrm{pH}$ dan suhu optimum dari enzim bromelain adalah 7,0 dan $37^{\circ} \mathrm{C}$.
\end{abstract}

Kata kunci: Ananas comosus, bonggol nanas, bromelain, aktivitas spesifik, pemurnian

\begin{abstract}
The aim of this study was to isolate and purify the bromelain extracted from part of pineapple fruit (Ananas comosus) through fractionation method using ammonium sulfate followed by dialysis. The highest specific activity on ammonium sulfate fraction was $50-80 \%$ (fraction 3) both for the sample of the core and the flesh of pineapple, each was $0.30 \mathrm{U} / \mathrm{mg}$ and $0.21 \mathrm{U} / \mathrm{mg}$. The fraction 3 of the core had a purity level 132.65 times of the crude enzyme while fraction 3 of the pineapple flesh had a purity level 108.47 times of the crude enzyme. From the dialysis process found the highest value of specific activity on fraction 3 of the pineapple core of $0.33 \mathrm{U} / \mathrm{mg}$ with a purity level of and 141.58 times of the crude enzyme. Fraction of the core has higher thermal
\end{abstract}


stability than the fraction of the flesh. The optimum temperature and $\mathrm{pH}$ of this enzyme was $37^{\circ} \mathrm{C}$ and 7.0 .

Keywords: Ananas comosus, pineapple core, bromelain, specific activity, purification

\section{PENDAHULUAN}

Salah satu faktor pemicu terbesar penyakit kardiovaskular adalah Diabetes. Diabetes mellitus merupakan penyakit metabolik akibat tingginya kadar glukosa dalam darah (hiperglikemia). Penyakit diabetes mellitus terjadi karena adanya kelainan sekresi insulin, kerja insulin atau keduanya (Maulina 2015). Oleh karena itu, diabetes merupakan salah satu masalah kesehatan yang sangat serius yang mengarah terjadinya komplikasi, seperti gangguan pada pembuluh darah (kardiovaskular), perubahan dalam fungsi trombosit, terutama peningkatan agregasi trombosit. Trombosit memainkan peran sentral dalam proses pembekuan darah dan timbulnya penyakit-penyakit kardiovaskular, penyebab terjadinya penyumbatan pada pembuluh darah dan kematian mendadak pada seseorang (Mosa, R.A., et al. 2011).

Dalam proses pengobatan penyakit ini, sering digunakan obatobatan anti-trombosit (antiplatelet) yang sintetik seperti Aspirin dan Clopidogrel. Namun, sepanjang proses pemakaiannya, obat-obatan tersebut memberikan beberapa efek samping, antara lain meningkatkan tekanan darah dan menyebabkan mual serta adanya resiko pendarahan. (Lusianawati, 2013). Hal ini, memicu pencarian obat-obatan antiplatelet herbal (tradisional) yang efektif dan tidak memberikan efek samping seperti yang berasal dari tanaman.

Nanas (Ananas comosus [L.] Merr.) merupakan komoditas andalan dalam perdagangan buah tropik yang menempati urutan ke dua terbesar setelah pisang. Indonesia merupakan produsen terbesar ke lima setelah Brazil, Thailand, Filipina dan Cina (Rugayah et al. 2012). Menurut Badan Pusat Statistik (2011), produksi buah nanas di Indonesia mengalami peningkatan dari tahun 2007 sampai 2009 yaitu 1.395 .566 ton, 1.433 .133 ton, dan 1.558 .196 ton. Sejalan meningkatnya kesadaran masyarakat akan nilai gizi serta bertambahnya permintaan bahan baku industri pengolahan buah, maka permintaan pasar cenderung meningkat. Produksi buah nanas yang cukup tinggi akan menyumbangkan limbah yang banyak pula. Limbah buangan dari buah nanas tersebut berupa batang, daun, dan bonggol (inti). Banyak varietas nanas (Ananas comosus) yang termasuk dalam famili bromeliaseae mengandung enzim proteolitik yang disebut bromelain. Limbah nanas yang berlimpah tersebut dapat dimanfaatkan secara optimal untuk menghasilkan produk yang memiliki nilai ekonomi lebih tinggi, misalnya sebagai sumber enzim bromelain yang potensil. Bromelain telah banyak digunakan dalam aplikasi terapeutik yang dikaitkan dengan efek farmakologisnya sebagai antithrombik, 
mengurangi penggumpalan dari plateles (antiplatelet), pembentukan plak di arteri dan pembekuan dalam darah. Semua efek ini membantu dalam pengobatan penyakit kardiovaskular (Bhattacharya 2008).

Enzim ini menguraikan protein dengan jalan memutuskan ikatan peptida dan menghasilkan protein yang lebih sederhana. Enzim bromelain terdapat dalam semua jaringan tanaman nanas. Sekitar setengah dari protein dalam nanas mengandung protease bromelain. Manfaat bromelain yang cukup luas di bidang farmakologi dan industri makanan mendorong banyak peneliti mempelajarinya lebih lanjut. Penelitian enzim bromelain pada tanaman nanas telah dimulai sejak tahun 1894 hingga saat ini. Berbagai cara isolasi telah dilakukan untuk mendapatkan enzim bromelain dari nanas dengan aktivitas enzim terbaik (Neta, et al. 2012).

Pada penelitian ini digunakan bagian bonggol buah nanas sebagai sumber enzim yang akan diisolasi dan dimurnikan melalui beberapa tahapan. Tahap awal, dilakukan proses isolasi dan pemisahan enzim kasar dengan metode fraksinasi pengendapan menggunakan ammonium sulfat diikuti dengan proses dialisis. Beberapa parameter yang akan dievaluasi adalah aktivitas proteolitik dan aktivitas spesifiknya.

\section{METODE PENELITIAN}

\section{A. Alat dan Bahan}

Alat-alat yang digunakan dalam penelitian adalah timbangan analitik, Spektrofotometer UV-Vis, centrifuge, shaker, blender, hotplate, magnetic stirer, pipet tetes, pipet volum, erlenmeyer, gelas kimia, labu ukur.

Beberapa bahan yang digunakan adalah Nanas, buffer fosfat $0,2 \mathrm{M}$, ammonium sulfat dan TCA 5\%.

\section{B. Prosedur Kerja}

\section{Preparasi Sampel dan Isolasi Enzim Kasar}

Bonggol dan daging buah nanas yang digunakan sebagai sumber enzim bromelain berasal dari perkebunan nanas di Gunung Cisalak, Cijeruk, Bogor. Preparasi diawali dengan memisahkan bonggol dari buahnya, menimbang masing-masing sampel sebanyak 500 gram, lalu memotong dan menghancurkannya menggunakan alat blender (dengan penambahan buffer fosfat dingin, suhu $\left.4^{\circ} \mathrm{C}\right)$. Campuran tersebut lalu disaring menggunakan kertas saring. Filtrat yang diperoleh kemudian disentrifugasi dengan kecepatan 6000 rpm selama 15 menit pada suhu $4^{\circ} \mathrm{C}$. Supernatan yang diperoleh dari masing-masing sampel merupakan larutan ekstrak kasar enzim bromelain (crude enzyme) kemudian disimpan dalam lemari pendingin yang akan digunakan sebagai sumber enzim.

\section{Fraksinasi Enzim Menggunakan Ammonium Sulfat}

Filtrat (ekstrak enzim kasar) dalam keadaan dingin kemudian difraksinasi melalui pengendapan bertingkat menggunakan garam ammonium sulfat pada berbagai tingkat kejenuhan (interval: 0-20\%, $20-50 \%$, 50-80\%). Larutan ekstrak enzim kasar sebesar $150 \mathrm{~mL}$ dimasukkan kedalam beaker glass 
yang ditempatkan pada wadah dingin mengandung garam (ice salt bath). Kemudian, secara perlahan ditambahkan garam ammonium sulfat (0-20\%) sambil diaduk menggunakan magnetic stirrer. Setelah penambahan garam selesai, proses pengadukan terus dilanjutkan selama 20 menit. Selanjutnya, larutan tersebut dibiarkan mengendap semalam dalam lemari pendingin. Larutan yang telah terendapkan lalu disentrifugasi dengan kecepatan $6000 \mathrm{rpm}$ selama 15 menit pada suhu $4^{\circ} \mathrm{C}$.

\section{Dialisis}

Proses dialisis diawali dengan mengikat kantung selofan pada satu ujung dengan suatu benang. Kemudian dimasukkan larutan enzim kedalam kantong dan diikat pada bagian ujung lainnya. Selanjutnya, kantung berisi enzim direndam dalam suatu larutan buffer fosfat $0,2 \mathrm{M} \mathrm{pH}=7,0$ dengan konsentrasi yang lebih encer dari buffer yang digunakan untuk melarutkan enzim. Proses di atas berlangsung sambil dilakukan pengadukan terus menerus menggunakan magnetic stirrer pada suhu $4^{\circ} \mathrm{C}$ dengan menempatkan pada ice salt bath.

\section{Uji Aktivitas Enzim dan Penentuan Kadar Protein}

Penentuan aktifitas enzim dilakukan dengan metode Kunitz menggunakan substrat kasein pada suhu $37^{\circ} \mathrm{C}$ selama 30 menit. Aktivitas enzim dihentikan dengan cara menambahkan 3 mL TCA 5\%. Kemudian, larutan diinkubasi dalam air es selama 30 menit. Kadar protein ditentukan berdasarkan Metode Lowry.

\section{Penentuan pH dan Temperatur Optimum}

Pengujian aktivitas enzim pada berbagai suhu dilakukan pada berbagai variasi suhu, mulai dari $30^{\circ} \mathrm{C} ; 35^{\circ} \mathrm{C}$; $37^{\circ} \mathrm{C} ; 40^{\circ} \mathrm{C}$; dan $45^{\circ} \mathrm{C}$. Pengujian aktivitas enzim pada berbagai $\mathrm{pH}$ dilakukan pada $\mathrm{pH} 6,0 ; 6,5 ; 7,0 ; 7,5$; dan 8,0 , dengan menggunakan buffer fosfat $0,2 \mathrm{M}$ ( $\mathrm{pH}$ 6-8). Selanjutnya, aktivitas enzim dihentikan dengan cara menambahkan $3 \mathrm{~mL}$ TCA $5 \%$.

\section{Uji Kestabilan Termal Larutan Sampel Enzim \\ Pengujian kestabilan termal} larutan sampel enzim dilakukan pada berbagai variasi suhu, mulai dari $40^{\circ} \mathrm{C}$ sampai $80^{\circ} \mathrm{C}$ selama 15 menit. Larutan sampel lalu diinkubasi pada suhu $37^{\circ} \mathrm{C}$ selama 30 menit. Selanjutnya, aktivitas enzim dihentikan dengan cara menambahkan $3 \mathrm{~mL}$ TCA 5\%.

\section{HASIL DAN PEMBAHASAN}

Ekstrak bromelain dari bonggol dan daging buah nanas telah dimurnikan melalui metode fraksinasi menggunakan garam ammonium sulfat, diikuti dengan proses dialisis. Enzim Kasar yang terdapat dalam bonggol dan daging buah nanas memiliki aktivitas spesifik sebesar $0,0023 \mathrm{U} / \mathrm{mg}$ protein dan $0,0019 \mathrm{U} / \mathrm{mg}$ protein. Hasil dari pemurnian enzim kasar menggunakan garam ammonium sulfat dengan konsentrasi yang berbeda dihasilkan fraksi enzim dengan aktivitas proteolitik dan kadar 
protein yang berbeda ditunjukkan pada Tabel 1.

Fraksi yang berasal dari bagian bonggol nanas pada tingkat kejenuhan ammonium sulfat $50-80 \%$ memiliki kandungan protein dengan aktivitas enzim bromelain paling tinggi. Fraksi lain, walaupun terdeteksi memiliki aktivitas bromelain, namun nilai aktivitas spesifik dan tingkat kemurniannya relatif lebih rendah. Fraksinasi dengan cara pengendapan menggunakan garam ammonium sulfat dapat dikatakan belum murni sepenuhnya meskipun sudah terbebas dari pengotor non-protein terlarut.

Tabel 1. Hasil Pemurnian Enzim Kasar dengan Amonium Sulfat

\begin{tabular}{|c|c|c|c|c|c|}
\hline \multirow{2}{*}{ Fraksi } & \multirow{6}{*}{$\begin{array}{c}\text { Volume } \\
\text { (ml) }\end{array}$} & \multicolumn{7}{|c|}{ Total } & $\begin{array}{c}\text { Aktivitas } \\
\text { Spesifik } \\
\text { (U/mg) }\end{array}$ & $\begin{array}{c}\text { Tingkat } \\
\text { Kemurnian } \\
\text { (U) }\end{array}$ & $\begin{array}{c}\text { Protein } \\
\text { (mg) }\end{array}$ & \\
\hline \multicolumn{5}{|c|}{ Bonggol Nanas } \\
\hline $\begin{array}{c}\text { Fraksi 1 } \\
(0-20 \%)\end{array}$ & 1.5 & 11.76 & 212.25 & 0.04 & 23.87 \\
\hline $\begin{array}{c}\text { Fraksi 2 } \\
(20-50 \%)\end{array}$ & 4.5 & 28.83 & 684.25 & 0.05 & 18.14 \\
\hline $\begin{array}{c}\text { Fraksi 3 } \\
(\mathbf{5 0 - 8 0 \% )}\end{array}$ & 1.5 & 16.86 & 54.75 & $\mathbf{0 . 3 0}$ & $\mathbf{1 3 2 . 6 5}$ \\
\hline \multicolumn{7}{|c|}{ Daging Buah Nanas } \\
\hline $\begin{array}{c}\text { Fraksi 1 } \\
(0-20 \%)\end{array}$ & 6 & 34 & 589 & 0.05 & 29.51 \\
\hline $\begin{array}{c}\text { Fraksi 2 } \\
(20-50 \%)\end{array}$ & 5 & 31.6 & 743.61 & 0.06 & 21.73 \\
\hline $\begin{array}{c}\text { Fraksi 3 } \\
(\mathbf{5 0 - 8 0 \% )}\end{array}$ & 2 & 16.66 & 78.55 & $\mathbf{0 . 2 1}$ & $\mathbf{1 0 8 . 4 7}$ \\
\hline
\end{tabular}

Aktivitas spesifik bromelain sebelum dan sesudah dialysis dapat dilihat pada Tabel 2. Fraksi 3 dari bagian bonggol nanas hasil proses dialisis memberikan tingkat kemurnian yang lebih tinggi dibanding fraksi sebelumnya yang diperlihatkan dengan meningkatnya nilai aktivitas spesifik dari 0,30 menjadi $0,33 \mathrm{U} / \mathrm{mg}$ dengan tingkat kemurnian sebesar 141,58 kali terhadap ekstrak enzim kasar dan persen kemurnian sebesar $0,92 \%$.
Sedangkan fraksi 3 dari bagian daging buah nanas hasil proses dialisis memberikan tingkat kemurnian yang lebih tinggi dibanding fraksi sebelumnya yang diperlihatkan dengan meningkatnya nilai aktivitas spesifik dari 0,21 menjadi $0,24 \mathrm{U} / \mathrm{mg}$ dengan tingkat kemurnian sebesar 122,21 kali terhadap ekstrak enzim kasar dan persen kemurnian sebesar 1,11\%. 
Tabel 2. Hasil Dialisis Enzim Bromelain

\begin{tabular}{|c|c|c|c|c|c|}
\hline \multirow{2}{*}{ Fraksi } & \multirow{6}{*}{$\begin{array}{c}\text { Volume } \\
\text { (ml) }\end{array}$} & $\begin{array}{c}\text { Total } \\
\text { Aktivitas } \\
\text { (U) }\end{array}$ & $\begin{array}{c}\text { Protein } \\
\text { (mg) }\end{array}$ & $\begin{array}{c}\text { Spesifik } \\
\text { (U/mg) }\end{array}$ & $\begin{array}{c}\text { Tingkat } \\
\text { Kemurnian }\end{array}$ \\
\hline \multicolumn{5}{|c|}{ Bonggol Nanas } \\
\hline $\begin{array}{c}\text { Fraksi 3 } \\
\text { Sebelum dialisis }\end{array}$ & 2 & 16.86 & 54.75 & 0.30 & 132.65 \\
\hline $\begin{array}{c}\text { Fraction 3 } \\
\text { Setelah dialisis }\end{array}$ & 3 & 32.15 & 97.8 & $\mathbf{0 . 3 3}$ & $\mathbf{1 4 1 . 5 8}$ \\
\hline \multicolumn{7}{|c|}{ Daging Buah Nanas } \\
\hline $\begin{array}{c}\text { Fraksi 3 } \\
\text { Sebelum dialisis }\end{array}$ & 2 & 16.67 & 78.56 & 0.21 & 108.47 \\
\hline $\begin{array}{c}\text { Fraction 3 } \\
\text { Setelah dialisis }\end{array}$ & 3.5 & 28.86 & 120.75 & 0.24 & 122.21 \\
\hline
\end{tabular}

Penentuan $\mathrm{pH}$ optimum dilakukan hanya untuk bromelain inti nanas setelah dialisis, karena memiliki aktivitas spesifik tertinggi. Pengaruh $\mathrm{pH}$ terhadap aktivitas enzim bromelain ditunjukkan pada Gambar 1. Aktivitas enzim bromelain meningkat dengan kenaikan $\mathrm{pH}$ dan menurun di atas $\mathrm{pH}$ 7,0 .
$\mathrm{pH}$ optimum yang diperoleh pada penelitian ini adalah 7,0 dengan nilai aktivitas enzim bromelain sebesar 6,51 $\mathrm{U} / \mathrm{ml}$. Dalam penelitian ini, Bresolin (2013) menemukan bahwa $\mathrm{pH}$ optimum isolat bromelain dari kulit nanas adalah 7,0 .

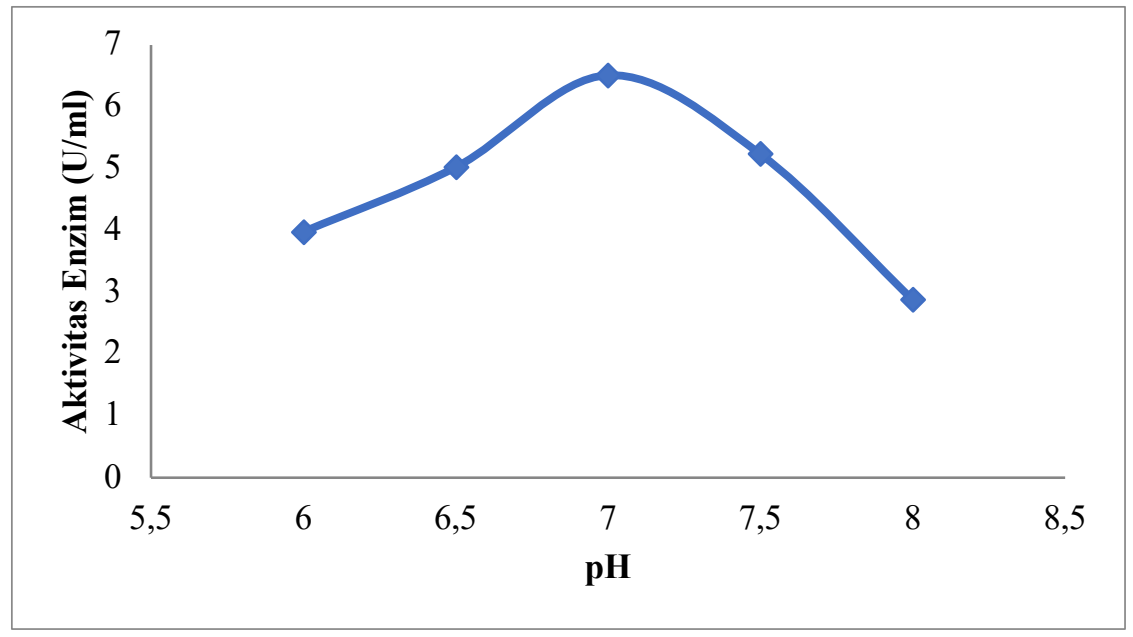

Gambar 1. Pengaruh $\mathrm{pH}$ terhadap Aktivitas Bromelain 
Aktivitas enzim dipengaruhi oleh suhu. Pada penelitian ini juga dilakukan penentuan suhu optimum hanya untuk bromelain dari inti nanas setelah dialisis, karena memiliki aktivitas spesifik tertinggi. Pengaruh suhu terhadap aktivitas enzim bromelain dapat dilihat pada Gambar 2. Aktivitas enzim bromelain meningkat seiring dengan kenaikan suhu dan di atas $37^{\circ} \mathrm{C}$ aktivitas enzim menurun. Suhu optimum yang diperoleh pada penelitian ini adalah $37^{\circ} \mathrm{C}$ dengan nilai aktivitas enzim bromelain sebesar 12,52 U/ml.

Jika suhu lebih tinggi dari $37^{\circ} \mathrm{C}$ maka aktivitas enzim akan menurun dan karena konformasi enzim protein mengalami perubahan (Maurer, 2001). Pada penelitian ini bromelain memiliki aktivitas tertinggi pada suhu $37^{\circ} \mathrm{C}$ dan menurun pada suhu sekitar $40^{\circ} \mathrm{C}$, namun masih memiliki aktivitas pada suhu sekitar $45^{\circ} \mathrm{C}(6,47 \mathrm{U} / \mathrm{ml})$.

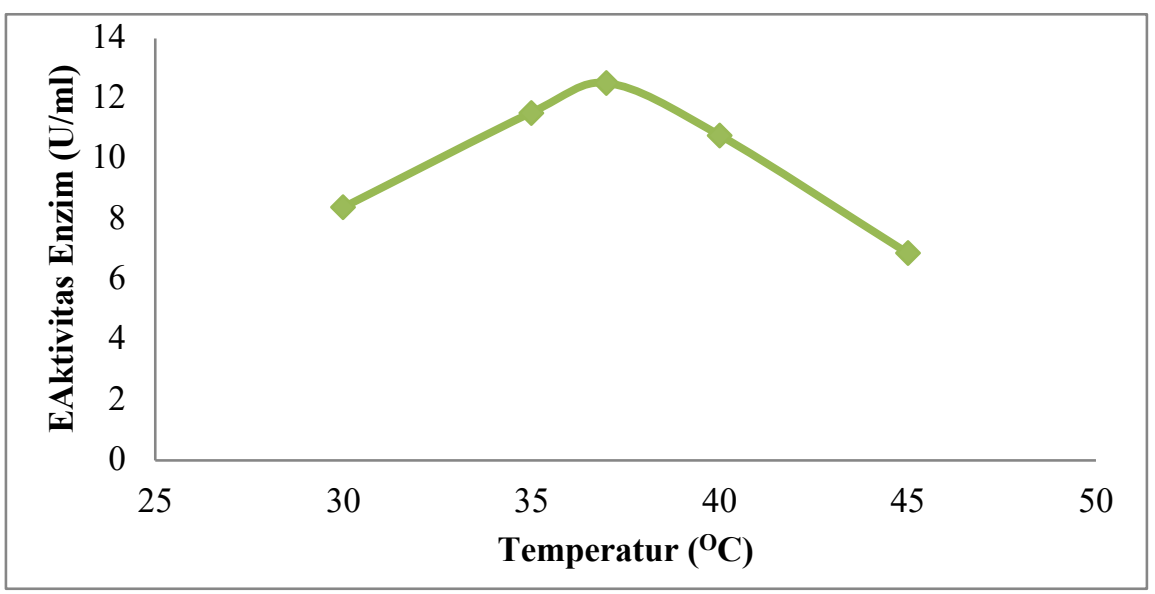

Gambar 2. Pengaruh Temperatur terhadap Aktivitas Bromelain

Penentuan uji stabilitas enzim perlu dilakukan untuk mengetahui berapa besar enzim bromelain ini memiliki kestabilan strukturnya terhadap perubahan suhu. Bromelain dari bonggol nanas mengalami inaktivasi pada suhu $80^{\circ} \mathrm{C}$. Sedangkan Bromelain dari daging buah nanas mengalami inaktivasi pada suhu $70^{\circ} \mathrm{C}$ seperti yang terlihat pada Gambar 3 .

Bromelain dari bonggol nanas memiliki stabilitas terhadap suhu lebih tinggi dibandingkan dengan bromelain dari daging buahnya. Kenaikan suhu melebihi suhu optimum enzim akan menyebabkan enzim mengalami denaturasi. Denaturasi menyebabkan sisi aktif enzim berubah sehingga afinitas substrat terhadap pusat aktif enzim terganggu sehingga enzim akan kehilangan aktivitasnya. Hasil ini menunjukkan bahwa bromelain dari inti nanas memiliki stabilitas termal yang lebih tinggi dari pada daging buah, jika suhu lebih tinggi dari $37^{\circ} \mathrm{C}$, enzim akan didenaturasi. Denaturasi disebabkan oleh perubahan sisi aktif enzim yang dapat menurunkan atau menghilangkan aktivitas enzim. (Ramalingam et al, 2012). 


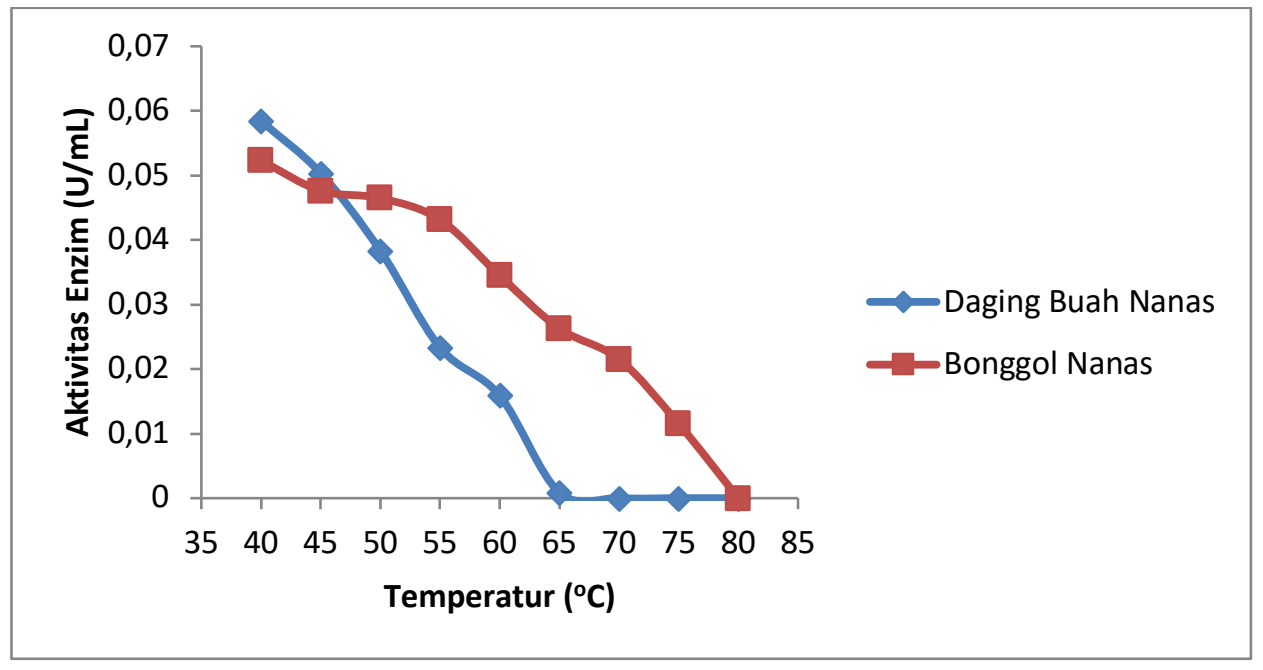

Gambar 3. Grafik Stabilitas Termal terhadap Aktivitas Enzim Bromelain pada Bonggol dan Daging Buah Nanas

\section{KESIMPULAN}

Pemurnian bromelain telah berhasil dilakukan dan dapat dilihat dari peningkatan nilai aktivitas dari bromelain. Pemurnian dengan metode fraksinasi bertingkat sampel ekstrak ezim kasar hasil isolasi dengan garam ammonium sulfat dan dialisis menunjukkan aktivitas proteolitik yang berbeda pada setiap sampel. Bonggol nanas memiliki aktivitas spesifik lebih tinggi dibandingkan daging buah nanas pada setiap proses. Bromelain dari bonggol nanas lebih tahan terhadap temperatur tinggi dibandingkan daging buah nanas. $\mathrm{pH}$ dan suhu optimum dari enzim bromelain adalah 7,0 dan $37^{\circ} \mathrm{C}$.

\section{DAFTAR PUSTAKA}

Bhattacharyya, B.K. 2008. Bromelain. India: Biotechnology and Molecular Biology, East India Pharmaceutical Works Ltd. Vol 7(4).
Bresolin, et al. 2013. Isolation and purification of bromelain from waste peel of pineapple for therapeutic application. Brazil: Campinas, SP.

Gautam, S.S., et al. 2010. Comparative Study of Extraction, Purification, and Estimation of Bromelain from Stem and Fruit of Pineapple Plant. India: Department of Pharmaceutics.

Lusianawati. 2013. Aktivitas Ekstrak dan Nanopartikel Ekstrak Kulit Kayu Mahoni sebagai Inhibitor EnzimHmg-Koa Reduktase. Bogor: Departemen Biokimia FMIPA Institut Pertanian Bogor.

Maulina, E.P. 2015. Studi Awal Uji Toksisitas Ekstrak Daun dan Batang Beligo (Benincasa Hispida) sebagai Inhibitor AGlukosidase. Depok: Departemen Kimia FMIPA Universitas Indonesia. 
Isolasi dan Karakterisasi Enzim Bromelain dari Bonggol dan Daging Nanas (Ananas comosus)

Maurer, H.R., 2001. Bromelain: biochemistry,pharmacology and medical use. Germany: Department of Biochemistry, Molecular Biology and Biotechnology, Institute of Pharmacy, University of Berlin.

Neta, J.L.V., et al. 2012. Bromelain Enzyme from Pineapple: In-vitro Activity Study under Different Micropropagation Conditions. Brazil: Springer Science.

Ramalingam, C., Srinath, R., Islam, N.N.2012. Isolation and Characterization of Bromelain from Pineapple (Ananas Comosus) and Comparing its antibrowning activity on apple juice with anti-browning agents. India: Elixir Food Science.

Rugayah, Anggalia, I., Cahya, Y. 2012. Pengaruh Konsentrasi dan Cara Aplikasi Iba (Indole Butiric Acid) terhadap Pertumbuhan Bibit Nanas (Ananas Comosus [L.] Merr.) Asal Tunas Mahkota. Bandar Lampung: Jurusan Agroteknologi Fakultas Pertanian Universitas Lampung. 